\title{
Direitos humanos, ética e a LITERATURA COMPARADA
}

\author{
Human Rights, Ethics and Comparative Literature
}

\author{
Cilza Bignotto ${ }^{1}$ \\ Carlos Cortez Minchillo ${ }^{2}$
}
${ }^{1}$ Universidade Federal de São Carlos, Departamento de Letras. São Carlos, SP, Brasil. E-mail: cilzab@gmail.com
${ }^{2}$ Dartmouth College, Departamento de Espanhol e Português. Hanover, NH, Estados Unidos E-mail: minchillo@dartmouth.edu

\section{EDITORES:}

Regina Zilberman

Gerson Roberto Neumann

COMO CITAR:

BIGNOTTO, Cilza;

MINCHILLO, Carlos

Cortez. Direitos humanos, ética e a literatura comparada. Rev. Bra. Lit. Comp., Porto Alegre, v. 23, n. 43, p. 5-7, mai.-ago., 2021. doi: https:// doi.org/10.1590/2596$304 \times 20212343 \mathrm{cbccm}$

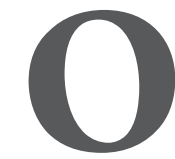
dossiê "Literatura comparada, ética e direitos humanos" toma forma em um quadro de crise sanitária avassaladora, que já vem sendo definida como genocídio por especialistas e organizações nacionais e internacionais. No momento em que escrevemos esta introdução, o número de mortos pela covid no Brasil se aproxima rapidamente da casa dos trezentos mil (COLLUCCI, 2020). A calamidade é geral, mas as pessoas mais atingidas pela doença são negras, mulheres e pobres (OLIVEIRA, 2021; BAQUI, 2020). Coincidentemente, aqueles que menos acesso têm aos direitos previstos, 73 anos atrás, pela Declaração Universal dos Direitos Humanos: habitação, alimentação, educação, lazer, assistência médica e segurança.

Como pensar a literatura e as artes nesse cenário sombrio?

Os artigos reunidos neste dossiê indicam que a literatura e as artes fazem a cartografia das regiões infernais onde vagam os sobreviventes, os marginalizados, os explorados, os mortos. Pela literatura, eles podem ganhar visibilidade e voz: têm a oportunidade de dar o seu recado e serem reconhecidos em sua humanidade, pela denúncia de injustiças, pela afirmação de suas identidades e pela reivindicação de direitos que lhes garantam a travessia para fora dos círculos da opressão, da morte, do esquecimento. Esse empenho por meio da palavra se converte em algo ainda mais necessário quando a esfera pública está saturada de discursos que não apenas questionam os princípios dos direitos humanos, como abertamente sustentam as mais ofensivas e violentas práticas desumanizadoras. Antonio Cândido, em 1988, no ano da aprovação da "Constituição Cidadã" no Brasil, 
vislumbrava "uma nota positiva no fundo do horror" pois entendia que a naquele momento os atos de barbárie já não ensejavam "motivo de celebração" (CANDIDO, 2011, p. 172-73). No entanto, hoje se confirma, com chocante nitidez, que os processos históricos são difusos e movediços. Todo avanço é reversível, e os direitos humanos devem ser permanentemente zelados e ampliados.

Em entrevista especialmente concedida para este número da revista, a historiadora Lynn Hunt sugere que os bens simbólicos como a literatura podem promover empatia e, sendo assim, talvez possam fortalecer a defesa dos direitos humanos. Mas Hunt lembra também que esse sentimento empático tem de encontrar uma feição política para conseguir desafiar normas sociais arraigadas. Partindo de diferentes ângulos, os textos reunidos neste dossiê giram em torno da questão de como a literatura e os estudos literários podem potencializar ou, ao contrário, recalcar o reconhecimento do outro - o oprimido, o subalterno, o marginalizado - e podem consequentemente subscrever ou rechaçar o resgate de sua dignidade e direitos e a legitimidade de seu lugar político.

Cristina Pinto-Bailey, em artigo que abre o dossiê, argumenta que a literatura da escritora Conceição Evaristo, ao emprestar voz a indivíduos negros oprimidos e silenciados, assume por si mesma uma função política, ao formatar um discurso que escancara a realidade historicamente ignorada e negada pela sociedade hegemônica branca. Em "Escrevivência, testemunho e direitos humanos em Olhos d'água de Conceição Evaristo", Pinto-Bailey oferece uma atenta leitura dos contos de Evaristo e defende, em consonância com o pensamento de Alzira Rufino, que "comunicar é politizar". A literatura afro-brasileira está em foco também no artigo de Felipe Fanuel Xavier Rodrigues, "Identidade poética de Lívia Natália”. Rodrigues estuda como a poetisa soteropolitana recorre à ancestralidade africana para potencializar os processos identitários que desconstroem o que ele chama de "hermenêutica epidérmica do racismo brasileiro" e clamam pela reparação dos danos causados pela discriminação de pessoas negras no Brasil.

Em seguida, Júlio César Souza de Oliveira investiga procedimentos discursivos empregados pelo escritor Rafael Gallo que suscitariam uma reflexão empática por parte do leitor. No artigo "Em torno dos direitos humanos: Veridicção na argumentação literária”, Souza de Oliveira recorre ao conceito de veridicção proposto por Algirdas Julien Greimas para analisar como Gallo constrói um discurso em defesa dos direitos humanos no conto Balas, levando o leitor "a crer no substrato de injustiça que permeia o mundo dos espoliados”.

Igualmente interessado nos dispositivos artísticos que permitem a expressão crítica contra formas de pensamento e atuação desumanizadoras, Paulo Dutra aponta as imagens de confronto que o rap norte-americano e o brasileiro empregam para relatar as experiências de afrodescendentes e vocalizar sua resistência. “The ultimate drive by": Racionais MC's, Ice Cube and the pursuit of blackness” [O derradeiro "drive by": Racionais MC's e Ice Cube em busca do "ser-negro"] lê em chave comparativa canções de Ice Cube e dos Racionais MC's, examinando como os respectivos textos denunciam e resistem ao embate físico e simbólico que, tendo raiz no regime escravocrata praticado nas Américas, não foi suprimido com a abolição.

Cilza Bignotto, uma das organizadoras deste dossiê, estuda as representações de personagens negros na literatura infantojuvenil produzida no Brasil nas últimas décadas do Império e na Primeira República. Em "Reescrevendo a cor negra: Monteiro Lobato e o racismo em livros infantis de sua época”, a autora revela que imagens de negros e negras em livros para crianças desse período são escassas 
e estigmatizantes, subtraindo sua autonomia e negando sua humanidade. Em chave comparativa, Bignotto estuda como Monteiro Lobato renova essa tradição, transformando "hierarquias sociais retratadas em livros para crianças, brasileiros e estrangeiros, por meio da irreverência e de transformação dos sentimentos de inferioridade, embaralhados e mudados de crianças para adultos, de amas para senhoras, de negros para brancos".

O dossiê prossegue com "A poesia do testemunho e o testemunho da poesia em Primo Levi e Varlam Chalámov”, no qual Marcelo Ferraz de Paula estuda as articulações entre poesia e catástrofe. $\mathrm{O}$ autor contrasta as maneiras pelas quais Levi e Chalámov entendem a função da poesia face ao terror perpetrado por estados totalitários e a supressão da humanidade nos campos de concentração nazistas e nos gulags soviéticos.

Finaliza o dossiê o artigo de Haidar Khezri, "Internal colonialism and the discipline of comparative literature in Iran" [Colonialismo interno e a disciplina da literatura comparada no Irão]. Khezri desloca a discussão para o campo dos estudos literários e apresenta um detalhado histórico da literatura comparada no Irã. Defende o autor que os estudos pós-coloniais preteriram a cultura e as línguas dos grupos subalternos não-persas dentro do Irã, acabando por instrumentalizar a disciplina da literatura comparada em função de propósitos políticos e religiosos. $\mathrm{O}$ autor propõe que, para manterem-se alinhados a princípios éticos e aos direitos humanos, os estudos comparados no Irã devem necessariamente ser mais inclusivos, reconhecendo a existência no país de comunidades não-persas e celebrando sua contribuição para a diversidade cultural e linguística do país.

\section{REFERÊNCIAS}

BAQUI, Pedro et al. Ethnic and regional variations in hospital mortality from COVID-19 in Brazil: a cross-sectional observational study. The Lancet. July 02, 2020. Disponível em: <https://doi.org/10.1016/ S2214-109X(20)30285-0>

CANDIDO, Antônio. “O direito à literatura”. In: Vários escritos. Rio de Janeiro: Ouro sobre Azul, 2011.

COLLUCCI, Cláudia. Com pandemia, SP registra 25\% de mortes a mais entre negros e 11,5\% entre brancos em 2020. Folha de S. Paulo, 19 de março de 2021. Disponível em: <https://www1.folha.uol.com. $\mathrm{br} /$ cotidiano/2021/03/com-pandemia-sp-registra-25-de-mortes-a-mais-entre-negros-e-115-entre-brancosem-2020.shtml>

OLIVEIRA, Ana Luísa Matos de. A ampliação das desigualdades raciais com a covid-19. Brasil de Fato. 05 de Abril de 2021. Disponível em: <https://www.brasildefato.com.br/2021/04/05/artigo-a-ampliacao-dasdesigualdades-raciais-com-a-covid-19> 